\title{
Agriculture Trade Scenario in India and Its Global Comparisons
}

\author{
Priyanka Mahajan \\ PG Department of Economics, Hindu College, Amritsar, India
}

\section{Email address:}

priyanka.mahajan@ymail.com

\section{To cite this article:}

Priyanka Mahajan. Agriculture Trade Scenario in India and Its Global Comparisons. International Journal of Agricultural Economics. Vol. 5, No. 3, 2020, pp. 63-70. doi: 10.11648/j.ijae.20200503.12

Received: February 21, 2020; Accepted: April 3, 2020; Published: June 17, 2020

\begin{abstract}
Indian economy has undergone structural changes over time with the anticipated decline in the share of agriculture in GDP. Despite a fall in its share from 55.1 percent of GDP in 1950-51 to 15.35 percent in 2015-16, the importance of agriculture has not diminished mainly for two reasons. First, country achieved self-sufficiency in food production at the macro level, but still a food deficit country facing massive challenges of high prevalence of malnourished children and high incidence of poverty. Second, the dependence of the rural workforce on agriculture for employment has not declined in proportion to the sectoral contribution to GDP. It is in this context of rapid transformation of trading environment in India and the world as a whole, an attempt has been made to examine the growth pattern of agricultural sector in India. The study also examined the commodity composition and structural changesinagricultural exportsand direction of agricultural exports of India from 199192 to 2013-14. The study reveals that in 24 years of post-reform period, the growth of agriculture and allied sector has not been stable. It is more or less dependent on monsoon which shows the backwardness of the Indian agriculture sector and failure of new reforms to improveagriculture sector. Trends in imports and exports show that integration of Indian agriculture with global economy has improved considerably during post reform period. But still percentage of imports in total imports is quite less and percentage of exports to totalexports has shown declining trend during the post reform period particularly post-WTOperiod. Regarding the international comparisons of India with other countries, the study depicts that India lags behind the world in all the major indicators of agricultural growth. India is also facing critical situation as regards the production and yield of selected commodities. As most of the farming in India is monsoon dependent. Irrigation problems have to be addressed by the government. Indian agricultural productivity is very less as compared to world standards due to use of obsolete farming technology. Sustainability in agriculture is of utmost importance. When proper technology (in water management at the regional, state and national levels as well as crop plan of what to produce and where to produce) is used, it will be a win-win situation for both the farmers and the country.
\end{abstract}

Keywords: Integration, Antidumping, Diversification, Farming Technology

\section{Introduction}

Indian economy has undergone structural changes over time with the anticipated decline in the share of agriculture in GDP. Despite a fall in its share from 55.1 percent of GDP in 1950-51 to 15.35 percent in 2015-16, the importance of agriculture has not diminished mainly for two reasons. First, country achieved self-sufficiency in food production at the macro level, but still a food deficit country facing massive challenges of high prevalence of malnourished children and high incidence of poverty. Second, the dependence of the rural workforce on agriculture for employment has not declined in proportion to the sectoral contribution to GDP. This has resulted in widening the income disparity between agricultural and non-agricultural sectors [1]. It is however revealed that the growth rate in the nineties indicated towards the need of sustainability in agriculture.

Under these circumstances, higher growth in agriculture assumes great importance and is a matter of concern for policy planners. However, there has been renewed policy thrust from the government since mid 2000's to revive agricultural growth through various developmental programmes such as interest subvention on crop loans, the 
National Food Security Mission, Rishartriya Krishi Vikas Yojana [3].

If we look at global perspective of agriculture, world agricultural exports have not kept pace with the growth in exports of either manufactured products or mining products. Over the years, growth in agriculture trade has been less strong than total merchandise trade, thereby resulting in its share decreasing from 12.6 percent in 1990 to only 9.4 percent in 2013-14 [8]. The most significant transformation that took place in the world economy in the 1990s was in the field of trade, especially agricultural trade. In 1995, agricultural trade was included as one of the areas in WTO. At the global level, WTO has an Agreement on Agriculture (AOA) whose main objective is to establish a fair and market-oriented agricultural trading system. A reform process would be initiated through the negotiation of commitments on support and protection, and through the establishment of strengthened and more operationally effective GATT rules and disciplines.

India has been a reasonably very conservative player in agriculture, and it was feared that any exposure to outside economy will jeopardise its own markets. But since the 1990s, India too saw an opportunity in liberalizing agricultural trade [14]. Thus, the development policy of India registered a thorough change from a physical control regime to a market-driven one. It is in this context of rapid transformation of trading environment in India and the world as a whole, an attempt has been made to examine the growth pattern of agricultural sector in India. The study also examined the commodity composition and structural changes in agricultural exports and direction of agricultural exports of India from 1991-92 to 2013-14. The whole study has been divided into three sections where Section I studies the growth rate of agricultural and allied sector and share of agricultural sector in GDP. Section II deals with the agricultural trade balance situation of India over 1991-92 to 2013-14. Section III gives the international comparisons of yield of selected commodities and depicts the India's position in world agriculture.

\section{Database and Methodology}

The study relies on secondary data compiled from various published sources. Data on agricultural imports and exports were collected from Directorate General of Commerce, Intelligence and Statistics, Ministry of Commerce. Data on International comparisons and commodity composition of exports and imports of agricultural commodities have been compiled from Agricultural Statistics at a Glance, Ministry of Agriculture, Government of India (various issues), Economic Survey, Government of India. 33 agricultural commodities have been considered. Eighteen countries have been considered for direction of agricultural exports at three points of time, i.e. 1995-96, 2001-02, 2005-06 and 2011-12. For analysis purpose, rate of change, compound annual growth rate and coefficient of variation has been calculated.

\section{Findings}

The deceleration in agriculture is best reflected in fluctuating growth rates of agriculture sector in post-reform period.

Table 1 shows that growth rate of agriculture and allied sector has shown wide fluctuations in post-reform period. The growth rate of agriculture was 6 percent in 1992-93 which decreased to zero percent in 1995-96. Then it jumped to 8.9 percent in 1996-97 on account of good monsoon, but it again registered negative movement of 1.3 percent in 1997-98. This rate again rose to 5.9 percent in 1998-99 but was only 0.3 percent in 2000-01. GDP growth rate of agriculture was quite high in $2010-11$ i.e. 8.3 percent but declined to around 4.71 percent in 2013-14. Regarding the percentage share of agriculture sector in GDP, the share of agriculture was 28.89 percent in total GDP in 1992-93 which declined to 22.31 percent in 2000-01 and then showed a continuous decline and reached a figure of 13.94 percent in 2013-14.

From the above analysis, it can be fairly concluded that in 24 years of post-reform period the growth of agriculture and allied sector has not been stable. It is more or less dependent on monsoon which shows the backwardness of the agriculture sector and failure of new reforms to develop the strongness of agriculture sector.

Table 1. GDP and Agricultural Growth Rates.

\begin{tabular}{llll}
\hline Year & GDPFc & $\begin{array}{l}\text { Agriculture and } \\
\text { Allied Sector }\end{array}$ & $\begin{array}{l}\text { Percentage share of } \\
\text { Agriculture Sector in GDP }\end{array}$ \\
\hline $1991-92$ & 1.4 & -1.4 & 28.54 \\
$1992-93$ & 5.4 & 6 & 28.89 \\
$1993-94$ & 5.7 & 3.1 & 28.24 \\
$1994-95$ & 6.4 & 5.2 & 27.8 \\
$1995-96$ & 7.3 & 0 & 25.73 \\
$1996-97$ & 8 & 8.9 & 26.19 \\
$1997-98$ & 4.3 & -1.3 & 24.47 \\
$1998-99$ & 6.7 & 5.9 & 24.39 \\
$1999-00$ & 8 & 2.8 & 23.27 \\
$2000-01$ & 4.1 & .3 & 22.31 \\
$2001-02$ & 5.4 & 5.5 & 22.42 \\
$2002-03$ & 3.9 & -4.9 & 20.13 \\
$2003-04$ & 8 & 8.2 & 20.32 \\
$2004-05$ & 7.1 & 1.1 & 19.03 \\
$2005-06$ & 9.5 & 4.6 & 18.27 \\
$2006-07$ & 9.6 & 4.6 & 17.37 \\
$2007-08$ & 9.3 & 5.5 & 16.81 \\
$2008-09$ & 6.7 & .4 & 15.77 \\
$2009-10$ & 8.6 & 1.5 & 14.64 \\
$2010-11$ & 8.9 & 8.3 & 14.59 \\
$2011-12$ & 6.7 & 4.4 & 14.37 \\
$2012-13$ & 4.9 & 1.42 & 13.95 \\
$2013-14$ & 4.7 & 4.71 & 13.94 \\
\hline
\end{tabular}

Source: Economic Survey, Government of India (2015). 
Table 2. Agriculture Trade and its Share in Total Trade (Rs. Crore).

\begin{tabular}{|c|c|c|c|c|c|c|c|}
\hline Year & $\begin{array}{l}\text { Agricultural } \\
\text { Imports }\end{array}$ & Total Imports & $\begin{array}{l}\text { Percentage } \\
\text { Share }\end{array}$ & Exports & Total Exports & $\begin{array}{l}\text { Percentage } \\
\text { Share }\end{array}$ & Trade Balance \\
\hline $1991-92$ & 1478.27 & 47850.84 & 3.09 & 7838.04 & 44041.81 & 17.8 & 6360.1 \\
\hline $1992-93$ & $2876.25(94.56)$ & $63374.52(32.44)$ & 4.54 & $9040.30(15.34)$ & $53688.26(21.89)$ & 16.84 & 6164.05 \\
\hline 1993-94 & $2327.33(-19.0)$ & $73101.01(15.34)$ & 3.18 & $12586.55(39.32)$ & $69748.85(29.91)$ & 18.05 & $10259.22(66.4)$ \\
\hline 1994-95 & $5937.21(155.1)$ & 89970.7 (23.07) & 6.6 & $13222.76(5.05)$ & $82673.4(18.53)$ & 15.99 & $7285.55(-28.98)$ \\
\hline $1995-96$ & $5890.1(-0.79)$ & $122678.14(36.35)$ & 4.8 & $20397.74(54.26)$ & 106353.35 (28.64) & 19.18 & $14507.64(99.13)$ \\
\hline $1997-98$ & $8784.19(32.84)$ & $154176.29(10.98)$ & 5.7 & $24832.45(2.78)$ & $130100.64(9.49)$ & 19.09 & $16048.26(-8.55)$ \\
\hline 1998-99 & $14566.48(65.82)$ & $178331.69(15.66)$ & 8.17 & $25106.4(2.73)$ & $139751.77(7.42)$ & 18.25 & $10944.16(-3.18)$ \\
\hline 1999-00 & $16066.73(10.29)$ & $215528.53(20.86)$ & 7.45 & $24170.66(-0.77)$ & $154095.2(13.84)$ & 15.91 & $9246.13(15.5)$ \\
\hline $2000-01$ & $12086.23(-24.77)$ & 228306.64 (5.9) & 5.29 & $28657.37(13.02)$ & $201356.4(26.56)$ & 14.23 & $16571.14(79.2)$ \\
\hline 2001-02 & $16256.61(34.50)$ & $245199.72(7.39)$ & 6.63 & $29728.61(3.73)$ & $209017.97(3.81)$ & 14.22 & $13472(-18.71)$ \\
\hline $2002-03$ & $17608.83(8.3)$ & $297205.87(21.21)$ & 5.92 & $34653.94(16.56)$ & $255137.28(22.06)$ & 13.58 & $17045.11(26.5)$ \\
\hline 2003-04 & $21972.68(24.71)$ & $359107.66(20.83)$ & 6.12 & $37266.52(7.54)$ & $293366.75(14.98)$ & 12.7 & $15293.84(-1.02)$ \\
\hline $2005-06$ & $21499.22(-5.75)$ & $660408.9(31.80)$ & 3.26 & $49216.96(18.3)$ & $456417.86(21.61)$ & 10.78 & $27717.74(47.5)$ \\
\hline 2006-07 & $29637.86(37.87)$ & $840506.31(27.27)$ & 3.53 & $62411.42(26.81)$ & $571779.28(25.27)$ & 10.92 & $32773.56(18.23)$ \\
\hline $2007-08$ & $29777.01(0.47)$ & $964849.76(14.79)$ & 3.09 & $77769.71(24.61)$ & $640172.14(11.96)$ & 12.15 & 47992.7 (46.93) \\
\hline 2008-09 & $34721.01(16.6)$ & $1154562(19.66)$ & 3.01 & $86435.2(11.4)$ & $785645.6(22.72)$ & 11 & $51714.19(7.7)$ \\
\hline $2009-10$ & $46378.23(33.57)$ & $1345763(16.56)$ & 3.44 & $99564.2(15.18)$ & $998765.7(14.43)$ & 9.66 & $53185.97(2.8)$ \\
\hline $2010-11$ & $57334.32(23.62)$ & $1683466.96(25.09)$ & 3.41 & 117483.61 (17.9) & $1142921.92(28.26)$ & 10.28 & $60149.29(13.09)$ \\
\hline 2011-12 & 82819.15 (44.45) & $2345461.24(39.87)$ & 3.53 & $187609.33(59.69)$ & $1465959.39(11.51)$ & 12.8 & $104790.1(74.2)$ \\
\hline $2012-13$ & $109211.51(31.86)$ & $2669839.78(13.38)$ & 4.09 & $230141.13(22.67)$ & $1634672.95(57.21)$ & 14.10 & $120929.6(15.4)$ \\
\hline 2013-14 & $179821(64.65)$ & $3245652(21.56)$ & 5.5 & $291741.13(51.74)$ & 1817891.10 & 16.04 & $111920.1(-7.4)$ \\
\hline
\end{tabular}

Source: Directorate General of Commerce, Intelligence and Statistics, Ministry of Commerce, Kolkatta.

\section{Scenario of Agriculture Trade Balance After Reforms}

India initiated liberalisation of its economy and trade with economic reforms in June 1991. As a part of it, India adjusted its exchange rate to market rate and relaxed restrictions on agricultural exports. This created a favourable environment for agricultural exports. From 1993-94, agriculture exports started increasing in leaps and bounds. Export earning almost doubled in three years between 1992-93 to 1995-96. Imports also increased at almost the same pace and net surplus generated by agriculture trade increased from Rs. 6164.05 crore in 199293 to Rs. 14507.64 crore in 1995-96.

High growth rate in agricultural exports that resulted from domestic liberalization during 1992-93 to 1994-95 witnessed further increase in the initial years of WTO and reached historical peak of Rs. 25,106 crore in 1998-99. However, after this year, earnings from agricultural exports starting moving downward and dropped to Rs. 24170.66 crore by year 1999-00. This happened despite further liberalization in agricultural exports announced in the Export-Import policy 1997-2002. Once again, agriculture exports started growing at a continuous rate from the year 2000-01 till 2013-14. Exports earnings increased at highest rate of 59.69 percent in year 2011-12. Imports also showed a continuous increasing trend from year 2001-02 (i.e. Rs. 6256.61 crore) to Rs. 179821 crore in year 2013-14 except for one year i.e. 200506 in which imports declined at the rate of 5.75 percent.
Agriculture trade balance always showed a surplus during the whole period. Trade balance increases from Rs. 4806.9 crore in $1990-91$ to Rs. 18790.81 crore in year $2004-05$ and reached a level of Rs. 111920.1 crore in year 2013-14.

These changes in trade balance indicate that there has been significant increase in trade orientation of Indian agriculture after 1990-91. Despite this increase in agricultural trade, imports of agriculture is relatively small as compared to the total import of the country. Percentage share of agricultural imports to total imports showed a fluctuating and decreasing trend during the whole period. Share of agricultural imports to total imports increased from 2.79 percent in 1990-91 to 8.17 percent in 1998-99 but then started decreasing and reached at a level of 3.01 percent in 2008-09.

While the share of agricultural exports in total export is almost double the share of agriculture imports. After 199091, there is decline in the share of agricultural exports from 18.47 percent in 1990-91 to 14.10 percent in 2012-13.

Trends in imports and exports show that integration of Indian agriculture with global economy has improved considerably during post reform period. But still percentage of imports in total imports is quite less and percentage of exports to total exports has shown declining trend during the post reform period particularly post-WTO period. Initial years of liberalization were favourable for the growth of exports and imports but post WTO years turned out to be a bit adverse for India's agricultural exports. Exports have seen recovery again in recent years. 


\section{Commodity Composition of Agricultural Exports}

Table 3 shows that in the year 1995-96, non-basmati rice (with 18.18 percent share), holds the major share of agricultural exports, followed by marine products (16.54 percent share) and oil meals (11.48 percent share). The share of other commodities namely basmati rice, cashew, coffee, castor oil and spices, in exports ranged between 4 percent to 7 percent in year 1995-96.

In year 2001-02, sharp decline has been witnessed in share of non-basmati rice (share decreased from 18.18 percent in 1995-96 to 4.73 percent in 2001-02). There was a meagre decline in share of oil meals (share decreased from 11.48 percent in 1995-96 to 8.04 percent in 2001-02). In year 200506 , there was an increase in the share of non-basmati rice and oil meals (share increased from 4.73 percent and 8.04 percent in 2001-02 to 9.17 percent and 10.68 percent in 2005-06 respectively) while in year 2011-12, there was an increase in the share of basmati rice ( 4.16 percent to 8.6 percent) and meat and meat preparation ( 3.86 percent to 7.86 percent).

Structural Changes in commodity composition show that share of commodities namely tea, cashew, non-basmati rice and coffee, marine products, oil meals, which have been the traditional exports from India, declined during this period. Share of non-basmati rice showed a drastic decline from 18.18 percent in 1995-96 to 4.83 percent in 2011-12. Export share of non-traditional exports like cotton raw including waste, guar gum meals, meat and meat preparations, spices, sesame and Niger seeds, sugar and molasses increased during the study period (share of cotton raw including waste increased rapidly from 0.99 percent to 12.05 percent in 2011 12).

Thus, performance of agricultural and allied products' exports show that India started diversifying exports of agricultural and allied products with increase in exports of large number of new agricultural and allied products apart from traditional exports.

Table 3. Commodity Composition of Agriculture and Allied Products Exports from India (Percentage Share).

\begin{tabular}{|c|c|c|c|c|c|}
\hline \multirow{2}{*}{ S. No. } & \multirow{2}{*}{ Commodities } & \multicolumn{4}{|l|}{ Year } \\
\hline & & $1995-96$ & 2001-02 & 2005-06 & 2011-12 \\
\hline 1. & Basmati Rice & 4.16 & 6.5 & 6.7 & 8.6 \\
\hline 2. & Cashew & 6.04 & 6.3 & 5.67 & 2.44 \\
\hline 3. & Cashew nut Shell Liquid & 0.007 & 0.018 & 0.02 & .003 \\
\hline 4. & Castor Oil & 3.63 & 2.22 & 2.06 & 2.56 \\
\hline 5. & Coffee & 7.35 & 3.89 & 3.49 & 2.41 \\
\hline 6. & Cotton Raw Including Waste & 0.99 & 0.15 & 6.18 & 12.05 \\
\hline 7. & Floriculture Products & 0.29 & 0.45 & 0.67 & .21 \\
\hline 8. & Fresh Fruits & 1.12 & 1.48 & 2.43 & 1.41 \\
\hline 9. & Fresh Vegetables & 1.45 & 2.04 & 2.02 & 1.61 \\
\hline 10. & Fruits/Vegetables Seeds & 0.20 & 0.22 & 0.19 & .15 \\
\hline 11. & Groundnuts & 1.12 & 0.89 & 1.12 & 2.92 \\
\hline 12. & Guargum Meals & 1.11 & 1.43 & 2.3 & 9.12 \\
\hline 13. & Marine Products & 16.54 & 20.9 & 14.07 & 9.25 \\
\hline 14. & Meat \& Meat Preparations & 3.06 & 4.23 & 5.86 & 7.86 \\
\hline 15. & Miscellaneous Processed Items & 2.64 & 2.57 & 2.16 & 2.12 \\
\hline 16. & Non-Basmati Rice & 18.18 & 4.73 & 9.17 & 4.83 \\
\hline 17. & Oil Meals & 11.48 & 8.04 & 10.68 & 6.56 \\
\hline 18. & Other Cereals & 0.08 & 0.41 & 1.13 & 3.05 \\
\hline 19. & Poultry and Dairy Products & 0.28 & 1.26 & 2.46 & .55 \\
\hline 20. & Processed Fruits and Juices & 1.00 & 1.82 & 1.32 & 0.92 \\
\hline 21. & Processed Vegetables & 0.69 & 0.70 & 1.04 & 0.58 \\
\hline 22. & Pulses & 0.64 & 1.31 & 2.44 & 0.59 \\
\hline 23. & Sesame and Niger Seeds & 1.25 & 2.16 & 1.75 & 1.54 \\
\hline 24. & Shellac & 0.31 & 0.25 & 0.35 & 0.14 \\
\hline 25. & Spices & 3.88 & 5.3 & 4.91 & 7.3 \\
\hline 26. & Spirit and Beverages & 0.22 & 0.44 & 0.600 & 0.8 \\
\hline 27. & Sugar and Mollases & 2.5 & 6.33 & 1.29 & 5 \\
\hline 28. & Mollases & - & 0.19 & 0.06 & 0.11 \\
\hline 29. & Sugar & - & 6.14 & 1.23 & 4.89 \\
\hline 30. & Tea & 5.72 & 6.10 & 3.6 & 2.3 \\
\hline 31. & Tobacco Manufactured & 0.33 & 0.80 & 0.66 & 0.61 \\
\hline 32. & Tobacco Unmanufactured & 1.85 & 2.06 & 2.27 & 1.61 \\
\hline \multirow[t]{2}{*}{33.} & Wheat & 1.79 & 4.72 & 1.23 & 0.57 \\
\hline & Total & 100 & 100 & 100 & 100 \\
\hline
\end{tabular}

Source: Calculated from data given in CMIE, Foreign Trade \& Balance of Payments (2001, 2006, 2013). 


\section{Direction of Agricultural Exports}

Direction of exports of agricultural and allied products given in Table 4 shows that in 1995-96, India's largest export market was Japan (having 9.31 percent share in India's exports), followed by Russia (7.71 percent), U.S.A. (7.68 percent), Indonesia (6.99 percent), U.A.E. (6.62 percent), Bangladesh (5.86 percent), U.K. (4.19 percent) and Saudi Arabia (3.59 percent share).

These eight nations together accounted for nearly 52 percent of exports in 1995-96. In 2001-02, U.S.A. served as a major market for country's exports (accounting for 12.66 percent of country's exports), followed by Japan, U.A.E., Saudi Arabia and Bangladesh (with export share $>5$ percent). The year 2005-06 has shown almost the same pattern as of 2001-02. In year 2011-12, India's largest export market was China (with 12.98 percent share), followed by USA, UAE,

\section{Saudi Arabia.}

Structural changes in direction of agricultural and allied products shows that as compared to 1995-96, countries namely U.S.A., Saudi Arabia, China, Malaysia, Belgium and Pakistan experienced increase in export share in 2011-12. Most important change has been in case of U.S.A. (share increased from 7.68 percent in 1995-96 to 12.71 percent in 2011-12) and of China (share increased from 1.20 percent in 1995-96 to 12.98 percent in 2011-12. While out of total 18 countries considered, the other 11 countries experienced a decrease in its share in total exports. Most important decline is in the case of Japan (share decreased from 9.31 percent in 1995-96 to 3.3 percent in 2011-12). Russia, Italy, France and Singapore have lost their importance and Belgium has emerged as an important market in exports of agricultural commodities from India.

Table 4. Destination of Exports: Agricultural and Allied Products (Percentage Share).

\begin{tabular}{|c|c|c|c|c|}
\hline \multirow{2}{*}{ Countries } & \multicolumn{4}{|l|}{ Year } \\
\hline & 1995-96 & 2001-02 & 2005-06 & 2011-12 \\
\hline World & 100.00 & 100.00 & 100.00 & 100.0 \\
\hline USA & 7.68 & 12.66 & 10.71 & 12.71 \\
\hline Japan & 9.31 & 7.56 & 5.11 & 3.03 \\
\hline Saudi Arabia & 3.59 & 5.51 & 5.92 & 3.88 \\
\hline Russia & 7.71 & 3.48 & 2.35 & \\
\hline UAE & 6.62 & 5.55 & 5.14 & 5.86 \\
\hline Netherlands & 3.52 & 3.11 & 2.50 & 1.82 \\
\hline Germany & 2.39 & 2.18 & 2.25 & 1.64 \\
\hline Banglades & 5.86 & 5.04 & 5.56 & 3.62 \\
\hline China & 1.20 & 2.13 & 7.22 & 12.98 \\
\hline Malaysia & 2.52 & 3.72 & 2.99 & 3.15 \\
\hline Italy & 2.57 & 1.57 & 1.71 & \\
\hline Indonesia & 6.99 & 4.27 & 2.60 & 2.96 \\
\hline Sri Lanka & 1.37 & - & - & 1.69 \\
\hline Belgium & - & 1.39 & 2.12 & 1.40 \\
\hline Pakistan & 0.64 & 1.56 & 1.92 & 1.74 \\
\hline
\end{tabular}

Source: CMIE, Foreign Trade and Balance of Payments (2001, 2006, 2013).

\section{International Comparisons}

Table 5 depicts India's position in World Agriculture in 2011.

As regards the arable land has been considered, the percentage share of India is 11.3 percent in the world's arable land which is second highest after the USA. India is also having second rank in economically active population in agriculture after China. If we look at crop production, India accords $3^{\text {rd }}$ rank in production of total cereals after China and USA while in the production of pulses, India got first rank.
India again lags behind China in the production of fruits and vegetables. The position of coffee production is quite worrysome as India's share is just 3.6 percent in total world production and is having seventh rank in the world. In animal products, India's is having $1^{\text {st }}$ rank in total milk production while the share of total meat production is quite less i.e. (2.1 percent) in the world. India is having $6^{\text {th }}$ rank in meat production. Thus, on the whole, table depicts that India lag behind the world in all the major indicators of agricultural growth.

Table 5. India's Position in World Agriculture in 2011.

\begin{tabular}{llllll}
\hline Item & India & \multirow{2}{*}{ World } & $\begin{array}{l}\text { Percentage } \\
\text { Share }\end{array}$ & India's Rank & Next to \\
\hline Total Area (M. Hec) & 329 & 13461 & 2.4 & 7 th & Russia Federation, Canada and USA, China, Brazil, Australia \\
Land Area & 297 & 13003 & 2.3 & 7 th & Russia Federation, China, USA, Canada, Brazil and Australia \\
Arable Land & 157 & 1396 & 11.3 & 2nd & USA \\
Total Population (Million) & 1241 & 6974 & 17.8 & 2nd & China \\
Agriculture & 595 & 2620 & 28.6 & 2nd & China \\
\hline
\end{tabular}




\begin{tabular}{|c|c|c|c|c|c|}
\hline Item & India & World & $\begin{array}{l}\text { Percentage } \\
\text { Share }\end{array}$ & India's Rank & Next to \\
\hline \multicolumn{6}{|c|}{ Economically Active Population (Million) } \\
\hline Total & 505 & 3324 & 15.2 & 2nd & China \\
\hline Agriculture & 273 & 1312 & 20.8 & 2nd & China \\
\hline \multicolumn{6}{|c|}{ Crop Production (Million Tonnes) } \\
\hline (a) Total Cereals & 288 & 2589 & 11.1 & 3 rd & China, USA \\
\hline Wheat & 86 & 701 & 12.3 & 2nd & China \\
\hline Rice & 157 & 722 & 21.7 & 2nd & China \\
\hline \multicolumn{6}{|l|}{ (b) Oil Seeds } \\
\hline Groundnut & 7 & 38 & 18.2 & 2nd & China \\
\hline Rapeseed & 8.1 & 59 & 13.7 & $3 \mathrm{rd}$ & Canada, China \\
\hline \multicolumn{6}{|c|}{ Fruits and Vegetables (Million Tonnes) } \\
\hline Vegetables and Melons & 105 & 1090 & 9.6 & 2nd & China \\
\hline Fruits excluding Melons & 74 & 637 & 11.6 & 2nd & China \\
\hline Potatoes & 42 & 373 & 11.3 & 2nd & China \\
\hline Onion (Dry) & 15 & 86 & 17.4 & 2nd & China \\
\hline \multicolumn{6}{|c|}{ 6. Commercial Crops (Milion Tonnes) } \\
\hline Sugarcane & 342 & 1800 & 19.0 & 2nd & Brazil \\
\hline Tea & 0.96 & 4.7 & 20.6 & 2nd & China \\
\hline Coffee (green) & 0.30 & 8.45 & 3.6 & 7th & Brazil, Vietnam, Indonesia, Colombia, Ethopia, Peru \\
\hline Jute and Jute like fibres & 1.96 & 3.58 & 54.7 & 1 st & \\
\hline Cotton & 8.5 & 26.14 & 32.5 & 2nd & China \\
\hline Tobacco Leaves & 0.83 & 7.37 & 11.3 & 3 rd & China and Brazil \\
\hline \multicolumn{6}{|l|}{ Animal Products } \\
\hline Total Milk (‘000 m) & 127 & 739.6 & 17.2 & $1 \mathrm{st}$ & \\
\hline (b) Eggs Total ('000 m) & 3490 & $\begin{array}{l}70615 . \\
6\end{array}$ & 4.9 & $3 \mathrm{rd}$ & China and USA \\
\hline (c) Total Meat ('000 m) & 6228 & 298871 & 2.1 & 6th & China, USA, Brazil, Germany and Russia \\
\hline \multicolumn{6}{|c|}{ (8) Agricultural Tractors (,000 numbers) } \\
\hline In Use & 3149 & 29320 & 10.7 & 2nd & USA \\
\hline
\end{tabular}

Source: FAO, Statistics Production Yearbook, Government of India.

\section{International Comparisons of Area, Production and Yield of Selected Commodities}

Low productivity has afflicted the growth of Indian agriculture. Table 6 reveals that though India accounted for 21.24 percent of global paddy production and is having the highest covered area under the production of paddy crop but the yield perhectare in 2012 was less than that of China and Indonesia. In production of paddy, India (152.6 million tonnes) lags behind China (206.09 million tonnes).

Similar is the case with wheat in which India covers highest area under the wheat production but in production and yield, India lags behind China. India's average yield level (3.17 tonnes/Hectares) is higher than global average which is a positive indicator. In case of maize and groundnut, while accounting 2.41 percent and 14 percent of global output, yield levels were 2.51 tonnes/hectares and 1.18 tonnes/hectares respectively in both the crops. India is having sixth rank in yield of maize after USA, China, Brazil, Indonesia and Mexico while in case of groundnut, India had $5^{\text {th }}$ rank in the yield and lags behind USA, China, Myanmar, Nigeria.

Similarly, while having 19.61 percent share in global output and having highest area under the production of sugarcane, India's yield per hectare was less than that of Thailand, Brazil and China. Thus on the whole, India is facing critical situation as regards the production and yield of selected commodities.

Table 6. Global Comparisons of Area, Production and Yield of Prinicipal Crops (2012).

\begin{tabular}{lllll}
\hline Country & Area (M. Hec) & Production (M. Tonnes) & Yield (Ton/Hec) & Production (\%) \\
\hline (1) Paddy & & & & 100 \\
World & 163.46 & 718.35 & 4.39 & 28.69 \\
China & 30.56 & 206.09 & 6.74 & 21.24 \\
India & 42.5 & 152.6 & 3.59 & 9.61 \\
Indonesia & 13.44 & 69.05 & 5.14 & 4.76 \\
Bangladesh & 11.7 & 34.2 & 2.92 & 6.08 \\
Vietnam & 7.75 & 43.66 & 5.63 & 100 \\
(2) Wheat & & & 3.12 & 17.87 \\
World & 216.64 & 674.88 & 5 & 14.06 \\
China & 24.14 & 120.58 & 3.17 & 5.59 \\
India & 29.90 & 94.88 & 1.77 & \\
Russia Federation & 21.28 & 37.72 & & \\
\hline
\end{tabular}




\begin{tabular}{lllll}
\hline Country & Area (M. Hec) & Production (M. Tonnes) & Yield (Ton/Hec) & Production (\%) \\
\hline USA & 19.83 & 61.76 & 3.11 & 9.15 \\
(3) Maize & & & 100 \\
World & 176.99 & 875.10 & 4.94 & 31.29 \\
USA & 35.36 & 273.83 & 7.74 & 23.8 \\
China & 34.97 & 208.26 & 5.96 & 8.15 \\
Brazil & 14.23 & 71.3 & 5.01 & 2.5 \\
Mexico & 6.92 & 22.07 & 3.19 & 2.21 \\
Indonesia & 3.96 & 19.38 & 4.89 & 2.41 \\
India & 8.4 & 21.06 & 2.51 & 100 \\
(4) Sugarcane & & & 37.81 \\
World & 25.76 & 1773.81 & 68.85 & 19.61 \\
Brazil & 9.41 & 670.76 & 71.3 & 7 \\
India & 5.09 & 347.87 & 68.34 & 5.44 \\
China & 1.80 & 124.17 & 68.81 & 3.27 \\
Thailand & 1.30 & 96.5 & 74.23 & 100 \\
Pakistan & 1.05 & 58.04 & 55.49 & 40.71 \\
(5) Groundnut (in Shell) & & & 14 \\
World & 24.63 & 41.27 & 1.68 & 7.44 \\
China & 4.73 & 16.88 & 3.57 & 3.41 \\
India & 4.9 & 5.78 & 1.18 & \\
Nigeria & 2.42 & 3.07 & 1.27 & \\
USA & .65 & 3.06 & 4.70 & 1.56 \\
Myanmar & .88 & 1.37 & & \\
\hline
\end{tabular}

Source: FAO, Regional Office for Asia and the Pacific, Bangkok.

\section{Conclusions}

The study reveals that in 24 years of post-reform period, the growth of agriculture and allied sector has not been stable. It is more or less dependent on monsoon which shows the backwardness of the Indian agriculture sector and failure of new reforms to develop the strongness of agriculture sector.

Trends in imports and exports show that integration of Indian agriculture with global economy has improved considerably during post reform period. But still percentage of imports in total imports is quite less and percentage of exports to total exports has shown declining trend during the post reform period particularly post-WTO period. Initial years of liberalization were favourable for the growth of exports and imports but post WTO years turned out to be a bit adverse for India's agricultural exports. The analysis of direction of trade indicates that agricultural and allied products' exports to USA, Saudi Arabia, China, Malaysia, Belgium and Pakistan experienced increase in export share in 2011-12 while 11 countries experienced a decrease in its share in total exports. Russia, Italy, France and Singapore have lost their importance and Belgium has emerged as an important market in exports of agricultural commodities from India.

Regarding the international comparisons of India with other countries, the study depicts that India lags behind the world in all the major indicators of agricultural growth. India is also facing critical situation as regards the production and yield of selected commodities.

To meet these challenges of Indian economy, following suggestions have been made:

1. As most of the farming in India is monsoon dependent. Irrigation problems have to be addressed by the government.

2. Indian agricultural productivity is very less as compared to world standards due to use of obsolete farming technology. Sustainability in agriculture is of utmost importance [15]. When proper technology (in water management at the regional, state and national levels as well as crop plan of what to produce and where to produce) is used, it will be a win-win situation for both the farmers and the country.

3. Scientific research should be encouraged to promote seeds which are mild on resource requirements but help the farmers in boosting the yields.

4. The Agreement on Agriculture (AOA) has to be viewed in an integrated manner along with other agreement viz. Agreement on Sanitary and Phytosanitary conditions, Agreement on TRIPS, Agreement on TRIMS and Agreement on Dispute Settlement [11].

5. Further, easy export licensing and technical know how regarding production, processing and marketing of exportable goods should be provided by the government.

6. There is also a need for more diversification of agricultural exports as it confirms more to traditional items measures like 'level playing field, through antidumping policies, reduction and phasing out of discriminatory restraints, allowing market access, opening up of the market, reduction in tariffs etc. are required to boost the agricultural exports [12].

7. To boost the exports of dynamic agricultural commodities, there is a need for agricultural research, as agricultural is becoming more capital intensive, knowledge and skill based activity. Structural strength of agricultural sector can be improved by investing more in $\mathrm{R} \& \mathrm{D}$ activities, introducing organic farming and environment friendly cropping practices, establishing two-tier organization for production and 
processing cooperative arrangement for processing and improving contribution of agricultural marketing organizations.

Finally, agriculture should be given the status of an industry in term of price factors, so as to enable it to avail of various other incentives.

\section{References}

[1] Chand. Ramesh and Tewari S, C, (1991), "Growth and Instability of Agricultural Exports and Imports of agricultural Commodities" Indian Journal of Agricultural Economics, Vol 46, No. 2.

[2] Chaturvedi, Sachin and Gunjan Nagpal (2003), "WTO and Product Related Environmental Standards: Emerging Issues and Policy Options", Economic and Political weekly, Vol. 38, No. 1.

[3] Deepika, M. G. (2004), "Changing Trade Scenario in Agriculture and its Implications for the Indian Economy", Thesis, Institute for social and Economic Change, Bangalore.

[4] Dhar, P. N. (1989), Constraints on Growth: Reflections on the Indian Experience, mimco, Institute of Economic Growth, Delhi.

[5] FAO, Statistical databases: http/:www.fao.org/statistical/.

[6] Government of India (1997) EXIM Policy, 1997-2002, Ministry of Commerce, New Delhi.

[7] Government of India (2001), Indian Economic Survey 200001, Akalank publications, New Delhi.
[8] Gulati, A. and Shashanka Bhide (1995), "What do the reforms have for agriculture?" Economic and Political Weekly, Vol. 30, No. 18.

[9] Martin, Will (2018), "A Research Agenda for International Agricultural Trade", Applied Economic Perspectives and Policy, Volume 40, Issue 1, March 2018, Pages 155-173.

[10] Mehta, Rajesh (2000), "Removal of QRs and Impact on India's Import", Economic and Political weekly, Vol 35, No. 19.

[11] OECD (1987), National Policies and Agricultural Trade, Paris.

[12] Rao, C. H. Hanumantha (1995), "New Economic Policyand Indian Agriculture", Indian Journal of Agricultural Economics, Vol 50, No. 3.

[13] Reserve Bank of India (2005), Handbook of Statistics of Indian Economy, Mumbai.

[14] Sathe, D, and Deshpande R. S. (2006), "Sustaining Agricultural Trade", Economic and Political Weekly, Vol. 41, Issue no. 52.

[15] Virmani, Arvind (2001), "India's 1990-91 Crisis Reforms, Myths and Paradoxes", Planning Commission, Working Paper, December, 2001.

[16] WTO, Trade Policy Review- Various Countries, Various Years, WTO, Geneva, www.wto.org.

[17] Government of India (2018), Analytical Study of India's Agricultural Exports Policy, Centre for Advance Trade Research, Department of Commerce. 